\title{
Influence of salinity stress on the uptake of magnesium, phosphorus, and yield of salt susceptible and tolerant sorghum cultivars (Sorghum bicolor L.)
}

\author{
Abida Kausar ${ }^{1}$, Munazza Gul12* \\ ${ }^{1}$ Department of Botany, GC Women University, Faisalabad, Pakistan \\ ${ }^{2}$ Department of Biochemistry, Faculty of Science, King Abdulaziz University, Jeddah, Kingdom of Saudi Arabia
}

\begin{tabular}{l}
\hline ARTICLE INFO \\
\hline Article history: \\
Received on: September 10, 2018 \\
Accepted on: December 27, 2018 \\
Available online: April 30, 2019 \\
\hline
\end{tabular}

\section{Key words:}

Sorghum, $\mathrm{NaCl}$, magnesium, phosphorus, yield.

\begin{abstract}
Sorghum is cultivated all over the world to satisfy the needs of food, feed, fiber, and industrial raw material. It is moderately tolerant to salinity and drought stress. The use of salt-tolerant varieties is one best way to increase plant productivity in saline soils. Present research work was planned to determine the effect of $\mathrm{NaCl}$ on four sorghum genotyes (two salt tolerant, i.e., Sandalbar and JS-2002; two salt sensitive, i.e., Noor and FJ-115). Data indicated that salt stress adversely affected the magnesium and phophorus contents in shoots and roots of all the four genotypes. Maximum magnesium and phosphorus accumulation were recorded in Sandalbar genotype, followed by Noor and the minimum occurred in the JS-2002 and FJ-115 sorghum genotypes in the case of shoots. The number of panicles/plant, grain weight/panicle, 1,000-grain weight, and grain yield/plant was also reduced by the $\mathrm{NaCl}$ stress. The maximum number of panicles and grain weight per panicle was obtained in Sandalbar (2.13), followed by JS-2002 (2.0) and the minimum number of panicles was present in FJ-115 (1.96) under saline stress. The maximum 1,000-grain weight decline was calculated in FJ-115 (69.3\%), followed by Noor (46\%) and the least decrease was noted in Sandalbar (15.2\%), followed by JS-2002 (19.4\%) in sorghum genotypes. However, the effect of salt stress was less prominent on salt tolerant genotypes as compared to saltsensitive ones in all these yield components. It was concluded that Sandalbar sorghum genotype has a potential to be developed for seed and for biomass production at salinity stressed areas.
\end{abstract}

\section{INTRODUCTION}

Salinity is a major threat to plant growth, development, and overall plant productivity [1]. Saline soils are increasing very rapidly, which cause the main hindrance to crop production worldwide [2]. Additions of toxic salts in the water lower the osmotic potential of water that leads to water shortage and less absorption of water by roots and ultimately causes the development of osmotic stress. Osmotic stress results in the disturbance of physiological and biochemical response of plants and adversely affect the plant development, yield, and production [3]. Growth and yield reduction of plants is a serious threat in salinity hit-areas. More than 800 million hectare of soils all over the world is salt affected

*Corresponding Author

Munazza Gull, Department of Biochemistry, Faculty of Science,

King Abdulaziz University, Jeddah, Kingdom of Saudi Arabia.

E-mail: munagull@hotmail.com
[4]. Salt stress is associated with high uptakes of toxic ions like sodium and chloride, which cause a reduction in the absorption of other minerals and essential nutrients. This also disrupts other normal metabolic processes of plants affecting ultimate growth and yield [5].

Sorghum (Sorghum bicolor L.) is an important industrial crop that was moderately tolerant of drought and salt stress. It is cultivated in arid and semi-arid areas of the world because of its ability to grow under water limiting conditions. Recent development studies about the genetic mechanism of sorghum showed that it is an important cellulose-providing crop. The cultivation of sorghum in drought and salinity hit areas for food sources is needed to exploit new genotypes of sorghum cultivars. The selection of salt-tolerant sorghum genotypes is the best strategy to increase crop production in saline soils [6]. It has been proved that increased salt tolerance in various crops is a good strategy, which could be applied in salt deteriorated areas of the world to alleviate salinity due to mutagenic nature of salt 
tolerance genotypes [7]. Keeping in view the above facts, present research work was planned to determine the extent of magnesium and phosphorus ions uptake potential and yield production of four sorghum genotypes under various salinity stress levels to select the best genotype for cultivation at salt-affected areas.

\section{MATERIALS AND METHODS}

The experiment was planned to determine the effect of salt stress on ion uptake, yield, and yield components of four sorghum genotypes (Salt tolerant: Sandalbar and JS-2002; Salt sensitive: Noor and FJ-115).

\subsection{Sorghum Seed Source and Plant Growth Experiment}

The seeds of four sorghum genotypes were obtained from Ayub Agricultural Research Institute, Faisalabad, Pakistan. The seeds of four sorghum genotypes were sown in earthen pots with $35 \mathrm{~cm}$ in diameter, filled with $10 \mathrm{~kg}$ of air-dried river sand under 0 and $100 \mathrm{mM} \mathrm{NaCl}$ solutions. Soil pH level was maintained at 7.0 by application of $\mathrm{H}_{2} \mathrm{SO}_{4}$ solution with the help of WissenschaftlichTechnische-Werkstätten (WTW) 530 PH meter observations. Experiment was conducted in a completely randomized block design with three replications and repositioned randomly at different times.

\subsection{Application of Various Levels of $\mathrm{NaCl}$ Salinity Stress}

The plants were subjected to 0 and $100 \mathrm{mM}$ levels of $\mathrm{NaCl}$ salt stress provided by Hoagland's nutrient solution in sand culture for 120 days.

\subsection{Ion Analyses}

The sorghum plants were grown in a greenhouse for 120 days, uprooted, and then oven dried for 7 days to carry out ions analyses. Magnesium and phosphorus ion contents were estimated according to the method of Jackson [8].

\subsection{Digestion}

The material for digestion was oven dried for 7 days. Wet digestion of dried sorghum plants material was performed according to the method of Wolf [9]. The $0.5 \mathrm{~g}$ of dried ground plant material was digested with $5 \mathrm{ml}$ of conc. $\mathrm{H}_{2} \mathrm{SO}_{4}$ and $0.5 \mathrm{ml}$ of $\mathrm{H}_{2} \mathrm{O}_{2}(35 \%)$ at $350^{\circ} \mathrm{C}$ on a hot plate until the digested mixture became colorless. The extract was volumed up to $50 \mathrm{ml}$ in volumetric flasks for determining magnesium and phosphorus ions contents.

\subsection{Magnesium Ions Determination}

Aliquot $0.5 \mathrm{ml}$ was taken in a flask and $1 \mathrm{ml}$ of distilled water was added. The few drops of Eriochrome Black $\mathrm{T}$ indicator and 10 drops of ammonia buffer were also added in this flask. The mixture was further titrated against $0.01 \mathrm{~N}$ EDTA. $\mathrm{Mg}+\mathrm{Ca}$ were determined using the following formula:

$\mathrm{Ca}+\mathrm{Mg}\left(\right.$ meq $\left.1^{-1}\right)=\frac{\text { Reading by the graph } \times \text { Normality }(0.01) \times 1,000}{\text { Size of the sample }}$

Amount of $\mathrm{Mg}$ was determined by subtracting $\mathrm{Ca}$ from $\mathrm{Mg}+\mathrm{Ca}$.

\subsection{Phosphorus Ions Determination}

For phosphorus (P) ions content analysis, $2 \mathrm{ml}$ of plant extract was dissolved in $2 \mathrm{ml}$ of Barton's reagent and total volume was made up to $50 \mathrm{ml}$ with distilled water. This mixture was kept for half an hour at room temperature for the development of color. The samples were recorded at $470 \mathrm{~nm}$ on a spectrophotometer (Hitachi-20). The concentration of phosphorus was estimated using a standard curve.

\subsection{Determination of Sorghum Yield Parameters}

The yield parameters of four sorghum genotypes that were recorded in this study included (a) number of panicles plant ${ }^{-1}$, (b) weight of grains panicles ${ }^{-1}(\mathrm{~g})$, (c) 1,000-grain weight (g), and (d) grain yield plant ${ }^{-1}(\mathrm{~g})$. Number of panicles/plant was recorded from five pre-tagged randomly selected plants. When the various genotypes have attained physiological maturity, the sorghum heads from each pot were cut, sun-dried, threshed, and winnowed manually. The grains were weighed (g) using sensitive balance from the bulk of the seeds of sorghum and adjusted to $13.5 \%$ moisture level. Weight of 1,000 seeds of sorghum obtained from 1,000 cleaned seeds.

\subsection{Statistical Analysis}

Analysis of variance (ANOVA) was conducted for all data and differences between means were compared at the 5\% level of significance using the Fisher's Protected LSD test. All statistical analyses were performed with software package COSTAT (v.6.3, Cohort software, California) [10].

\section{RESULTS AND DISCUSSION}

The main objective of the present investigation was to estimate the extent of magnesium and phosphorus ions uptake potential and yield parameters of four sorghum genotypes under various salinity stress levels. The effect of salinity stress was also compared between saline and non-saline treatments.

\subsection{Magnesium Contents in Shoots and Roots}

Magnesium contents in shoots and roots showed significantly adverse influence caused by salinity in sorghum genotypes (Table 1; Fig. 1a and b). The highest value was obtained under non-saline conditions and the minimum was recorded under salinity stress medium in all sorghum genotypes. The differences between the genotypes were significant in the shoots (Fig. 1a), while they did not change in different genotypes with regard to roots (Fig. 1b). Maximum magnesium accumulation was recorded in Sandalbar genotype, followed by Noor and the minimum was measured in the JS-2002 and FJ-115 sorghum genotypes in the case of shoots. The interaction salinity and genotypes were significant in case of shoots, while non-significant in case of roots for magnesium content. However, in non-saline conditions, the highest value of magnesium content was obtained in Sandalbar genotype, followed by Noor and minimum was recorded in FJ115 , followed by JS-2002.

It was observed that the highest value of magnesium contents was maintained by Sandalbar genotype, followed by JS-2002 under a 
Table 1: Mean squares values from analyses of variance of data for magnesium and phosphorus contents of both shoots and roots of four sorghum genotypes subjected to $\mathrm{NaCl}(0,100 \mathrm{mM})$ salt stress.

\begin{tabular}{|c|c|c|c|c|c|}
\hline S.V. & Degree of freedom & $\begin{array}{l}\text { Magnesium of shoots } \\
\quad\left(\mathrm{mg} \mathrm{g}^{-1} \mathrm{D} \text {. W. }\right)\end{array}$ & $\begin{array}{l}\text { Magnesium of roots } \\
\left(\mathrm{mg} \mathrm{g}^{-1} \mathrm{D} \text {. W. }\right)\end{array}$ & $\begin{array}{l}\text { Phosphorus of shoots } \\
\quad\left(\mathrm{mg} \mathrm{g}^{-1} \mathrm{D} \text {. W.) }\right.\end{array}$ & $\begin{array}{l}\text { Phosphorus of roots } \\
\text { ( } \mathrm{mg} \mathrm{g}^{-1} \text { D. W.) }\end{array}$ \\
\hline Genotypes (G) & 3 & $46.093^{* *}$ & $39.015^{* *}$ & $1.135^{* *}$ & $6.859^{* *}$ \\
\hline $\mathrm{NaCl}$ treatments (S) & 1 & $7.333^{*}$ & $0.237^{\mathrm{NS}}$ & $0.030^{\mathrm{NS}}$ & $0.426^{*}$ \\
\hline $\mathrm{G} \times \mathrm{S}$ & 3 & $3.128^{*}$ & $0.957^{\mathrm{NS}}$ & $0.078^{*}$ & $0.521^{* *}$ \\
\hline Error & 16 & 2.145 & 0.625 & 0.019 & 0.090 \\
\hline Total & 23 & & & & \\
\hline
\end{tabular}

$*, * *, * *=$ Significant at $p \leq 0.05,0.01$, and 0.001, respectively.

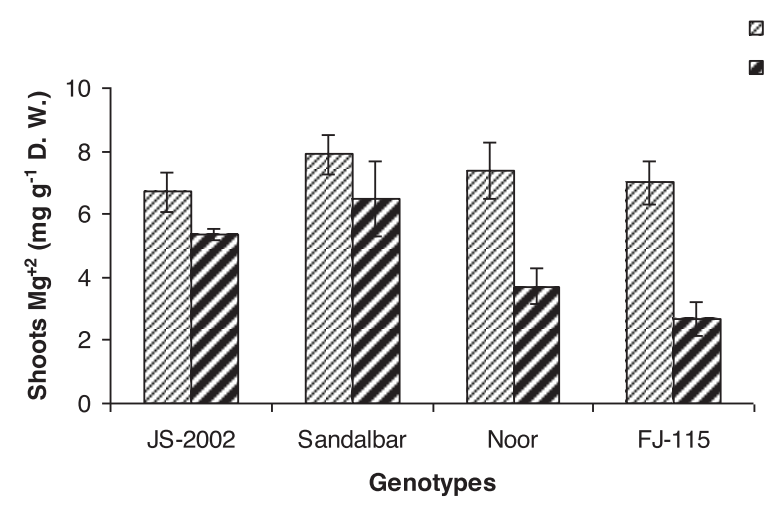

(a)

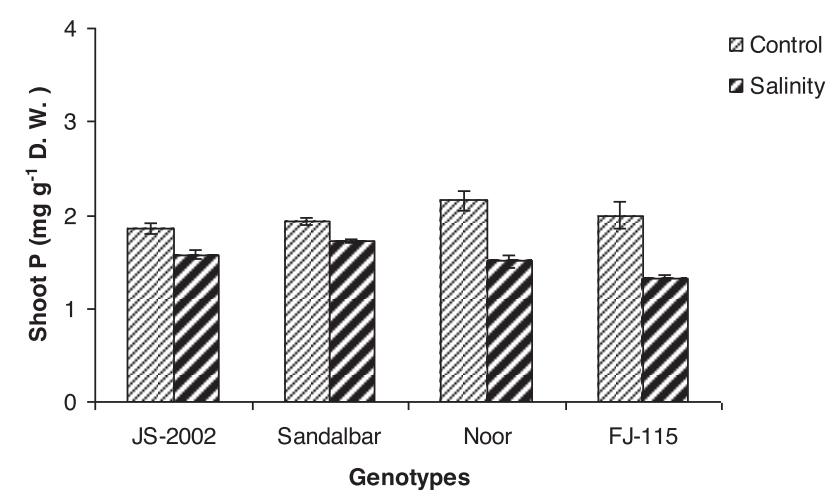

(c)

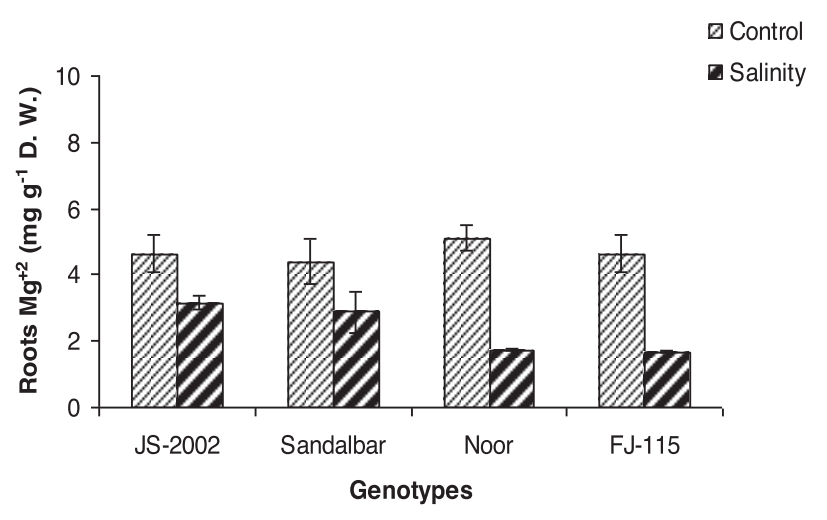

(b)

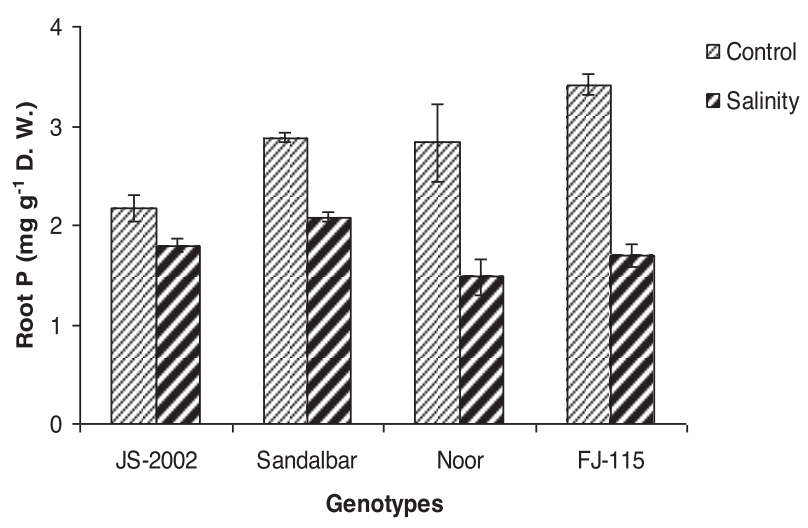

(d)

Figure 1: Effect of salt stress ( 0 and $100 \mathrm{mM} \mathrm{NaCl}$ ) on magnesium (a and b) and phosphorus ( $\mathrm{c}$ and d) contents in both shoots and roots of four sorghum genotypes. Bars represent standard error. Different letters indicate significant differences in all treatment means from repeated-measures ANOVA, $p<0.05$. In this case, the means and errors of the three experiments have been shown.

high level of salinity stress. In contrast, the minimum magnesium contents were obtained in genotype FJ-115, followed by Noor under saline stress (Table 1; Fig. 1a and b). Different ion uptake potential of sorghum varieties to soil salinity stress was caused by genetics variations of sorghum. Many previous studies indicated that salt stress was inversely related to the growth and ions uptake in plants [11-13].

\subsection{Phosphorus Content in Shoots and Roots}

Phosphorus $(\mathrm{P})$ content in shoots and roots significantly decreased with the application of $\mathrm{NaCl}$ stress in all the genotypes of sorghum (Table 1). However, P content in roots was found higher than in shoots (Fig. 1c and d). The variations among different sorghum genotypes were non-significant for both shoots and roots (Table 1). In shoots, maximum P contents were determined in genotypes 
Sandalbar and Noor, followed by JS-2002 and FJ-115. Similarly, in case of roots, a higher concentration of $\mathrm{P}$ was obtained in FJ-115 and Sandalbar genotypes (Fig. 1d). The differences among the genotypes in both roots and shoots were significant. Interaction between salinity and genotypes was significant in both cases. Sorghum genotypes Noor and FJ-115 maintained a higher concentration of $\mathrm{P}$ in their shoots (Fig. 1). Minimum P contents were recorded in Sandalbar genotype, followed by JS-2002 in both shoots and roots under non-saline environments. But under salt stress condition, the minimum $\mathrm{P}$ concentrations were found in FJ-115, followed by Noor and JS-2002 genotypes. In contrast, the maximum P was recorded in Sandalbar, followed by JS-2002, FJ-115, and Noor genotypes in roots under salt stress. Analysis of variance showed that salinity reduced the $\mathrm{P}$ contents in both roots and shoots in all sorghum genotypes. Previous studies reported that soil salt stress increases $\mathrm{Mn}, \mathrm{Zn}$, and $\mathrm{P}$ contents but decreases $\mathrm{Fe}$ and $\mathrm{K}$ ion concentrations in plants. Accumulation of $\mathrm{Na}^{+}$with increasing levels of salt stress was accompanied with the reduction in levels of $\mathrm{Ca}^{2+}, \mathrm{Mg}^{2+}$, and $\mathrm{K}^{+}$in leaves [14,15].

\subsection{Effect of Salinity on Yield and Yield Components}

\subsubsection{Number of panicles per plant}

Panicle number per plant is an important yield attribute of sorghum which contributes to grain yield. Crops with higher panicle number could have higher grain yield. Panicle number was significantly influenced by the salinity stress in all sorghum genotypes [16]. Number of panicles was significantly decreased under salt stress as compared to non-saline conditions. The number of panicles per plant differed non-significantly with respect to different sorghum genotypes (Table 2). The interactions between the salinity and genotypes with reference to number of panicles also showed non-significance. The maximum number of panicles was recorded in genotype FJ-115 (3.25), followed by Noor (2.75), JS-2002 (2.65), and Sandalbar (2.61) genotypes of sorghum in non-saline environments (Fig. 2a). In contrast, the maximum number of panicles was obtained in Sandalbar (2.13), followed by JS-2002 (2.0) and minimum number of panicles was present in FJ-115 (1.96) closely followed by Noor (1.91) genotype under saline conditions (Fig. 2a). Data regarding number of panicles supported that Sandalbar and JS-2002 showed the best performance in behavior in saline environments than Noor and FJ115 sorghum genotypes. Salinity decreased the plant productivity in all sorghum genotypes $[17,18]$.

\subsubsection{Weight of grains per panicle}

All the genotypes differed significantly from each other with respect to grain weight of panicles. Salinity caused a negative effect on all sorghum genotypes (Table 2). The highest grain weight was measured in Sandalbar (15.4 g) closely followed by JS-2002 (14.8 $\mathrm{g})$ and minimum grain weight was present in Noor (11.4 g) closely followed by FJ-115 (12.5 g) in sorghum genotypes (Fig. 2b). The interaction between salinity and genotypes for the weight of grains was also significant. The higher grain weight was gained in FJ-115 (18.2 g) closely followed by Sandalbar (17.1 g) and JS-2002 (16.7 g) and the minimum was in Noor (15.3 g) in sorghum genotypes in the non-saline medium. In contrast, the maximum grain weight was gained in Sandalbar closely followed by JS-2002 and minimum was recorded in FJ-115 closely followed by Noor genotypes of sorghum in salt stress. Soil salinity reduced the yield potential in different crops $[19,20]$. The data of this study showed similar conclusions that weight of grains panicle ${ }^{-1}$, number of panicles plant $^{-1}$, grain yield plant $^{-1}$, and 1,000-grain weight (Table 2; Fig. 2a and b) were reduced at $100 \mathrm{mM} \mathrm{NaCl}$ [21-23].

\subsubsection{Thousand grain weight}

It is an important yield determining component and reported to be a genetic trait that is influenced least by environmental factors [24]. The analysis of variance showed that the main effect of salt stress on 1,000-seed weight and that of sorghum genotypes was significant. Salinity adversely reduced the 1,000-grain weight (g) in all four sorghum genotypes and they differed significantly from each other in 1,000-grain weight (Table 2). The maximum 1,000-grain weight was produced in JS-2002 (19.5 g), followed by Sandalbar (18.2 g) and the minimum 1,000-grain weight was obtained in FJ-115, followed by Noor (Fig. 3a). The interactive effect of salinity and genotypes was also significant and highest 1,000-grain weight was gained by Noor $(21.7 \mathrm{~g})$ and JS-2002 $(21.6 \mathrm{~g})$, followed by Sandalbar (19.7 g) and FJ-115 (18.6 g) in non-saline environments (Fig. 3a). However, in saline conditions, the maximum decline in 1,000-grains weight was calculated in FJ115 (69.3\%), followed by Noor (46\%). However, for 1,000-grain weight yield component, genotypes Sandalbar (15.2\%) and JS2002 (19.4\%) performed better among sorghum genotypes under salt stress. Yield component 1000-grains weight data concluded that salinity is a serious threat to agricultural areas, which reduces the crop yield and plant productivity negatively $[3,8,12,14,25,26]$. The adverse effect of salinity can be tolerated by selection and cultivation of resistant sorghum genotypes in saline areas, highlighting the importance of present investigations.

\subsubsection{Grain yield per plant}

Grain yield was negatively and significantly influenced by salinity stress $(57.3 \mathrm{~g}$ ) in all sorghum genotypes (Table 2). The interactive effect between salt stress and genotypes were significant in all sorghum genotypes. The highest inhibition was estimated in FJ$115(78.1 \%)$, followed by Noor (66\%) and the minimum inhibition was recorded in Sandalbar (36.3\%), followed by JS-2002 (42.4\%) in sorghum genotypes (Fig. 3b). Corroborating the results of this study, it is well documented now that salinity restricted crop production, caused stunted growth, and lowered the yield and yield components. Salt stresses are very critical for meeting crop needs and considerable opportunities exist for yield improvement [14]. Plants may tolerate salinity stress to a certain level if salt resistant genotypes were cultivated [15]. It was also determined that salt tolerant lines did not significantly reduce leaf and stem dry weights, while the salt sensitive genotypes significantly reduced yield with elevating level of soil salt stress [27]. Many sorghum genotypes with high genetic potential have proved their ability to tolerate salt effect without a decline in growth and yield components. Usually, salinity induced adverse effects on various physiological and biochemical processes which eventually reduced the growth and yield of plants $[3,5]$. Plant tolerance in the rooting medium was 
Table 2: Mean squares values from analyses of variance of data for number of panicles/plant, grain weight/panicle, 1,000-grain weight, and grain yield/plant of four genotypes of sorghum subjected to $\mathrm{NaCl}(0,100 \mathrm{mM})$ salt stress.

\begin{tabular}{|c|c|c|c|c|c|}
\hline S.v. & Degree of freedom & number of panicles/plant & grain weight/panicle (g) & 1,000 -grain weight (g) & grain yield/plant (g) \\
\hline Genotypes (G) & 3 & $3.977^{* *}$ & $269.273^{* * *}$ & $338.100^{* *}$ & $4502.998^{* *}$ \\
\hline $\mathrm{NaCl}$ treatments (S) & 1 & $0.105^{\mathrm{NS}}$ & $20.842^{* *}$ & $61.981^{* *}$ & $90.316^{\mathrm{NS}}$ \\
\hline $\mathrm{G} \times \mathrm{S}$ & 3 & $0.179^{\mathrm{NS}}$ & $20.969^{* * *}$ & $33.469^{* * *}$ & $280.717^{* * *}$ \\
\hline Error & 16 & 0.116 & 2.050 & 1.004 & 49.414 \\
\hline Total & 23 & & & & \\
\hline
\end{tabular}

$*, * *, * * *=$ Significant at $p \leq 0.05,0.01$, and 0.001 , respectively.

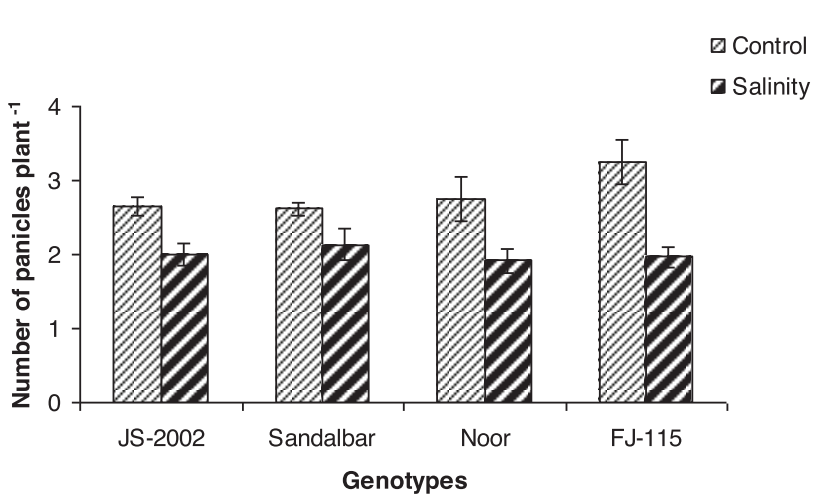

(a)

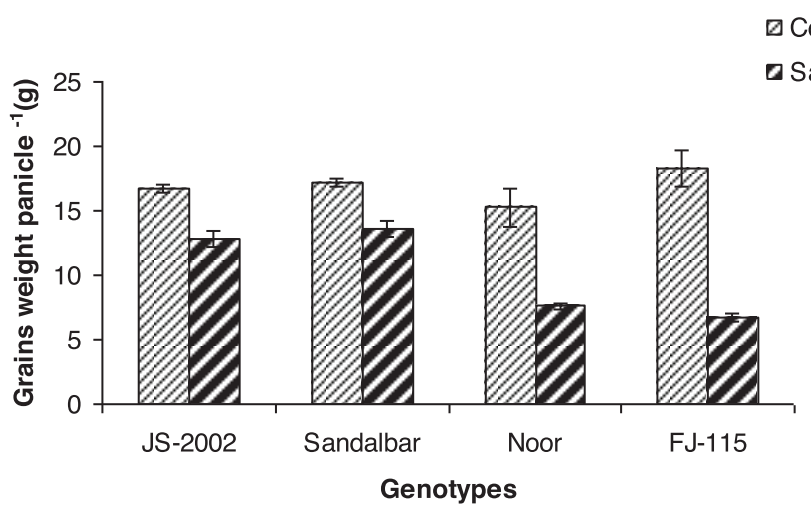

(b)

Figure 2: Effect of salt stress ( 0 and $100 \mathrm{mM} \mathrm{NaCl})$ on number of panicles/plant (a) and grain weight/panicle (b) on four sorghum genotypes. Bars represent standard error. Different letters indicate significant differences in all treatment means from repeated-measures ANOVA, $p<0.05$. In this case, the means and errors of the three experiments have been shown.

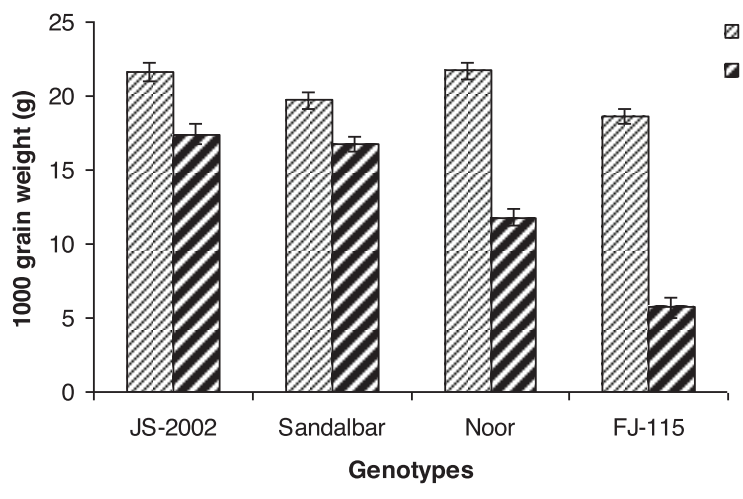

(a)

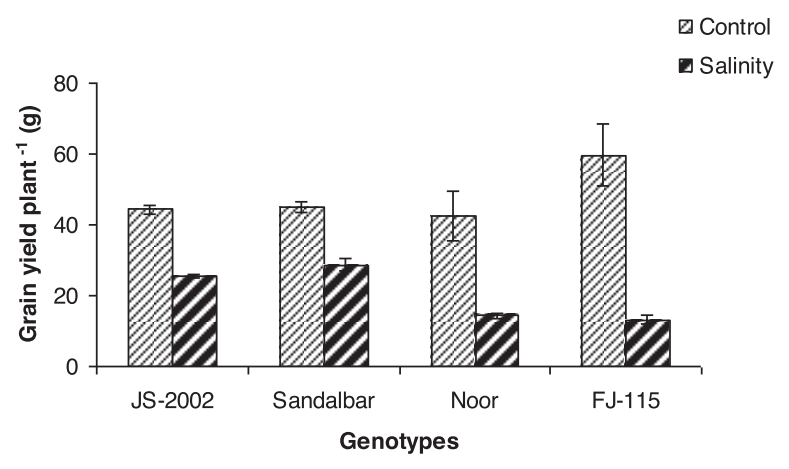

(b)

Figure 3: Effect of salt stress $(0$ and $100 \mathrm{mM} \mathrm{NaCl})$ on 1,000-grain weight (a) and grain yield/plant (b) of four sorghum genotypes. Bars represent standard error. Different letters indicate significant differences in all treatment means from repeated-measures ANOVA, $p<0.05$. In this case, the means and errors of the three experiments have been shown.

found under genetic control and these genetic variations are the fundamental tools for crop improvements [3,20,21,28-30].

\section{CONCLUSIONS}

The study was conducted to determine the uptake of magnesium, phosphorus contents, yield, and yield components potential of four sorghum genotypes under salt stress conditions. The effect of salt stress was less prominent on salt tolerant genotypes as compared to salt-sensitive ones in ions uptake and all yield components. Sandalbar sorghum genotype showed a great potential to be cultivated for seeds and increased biomass production in salinity stressed areas successfully. The salt tolerant and salt sensitive genotypes can be distinguished and selected on the basis of growth, 
yield, and overall plant productivity under saline environments. Sorghum showed great potential for genetic variations, which provides a source to be cultivated in salt-affected areas to enhance its productivity. This data might be helpful for further breeding programs in sorghum and other crops as well.

\section{CONFLICT OF INTEREST}

The authors would hereby like to declare that there is no conflict of interests that could possibly arise.

\section{ACKNOWLEDGMENTS}

We are grateful to the Department of Botany, GC (W) University, Faisalabad, Pakistan for supporting and providing the research facilities in this study and the seed manager of AYUB Agriculture Research Institute (Government of Punjab, Pakistan) and Seed Certification Department of Pakistan for providing seeds of sorghum cultivars.

\section{REFERENCES}

1. Huang S, Spielmeyer W, Lagudah ES, James RA, Platten JD, Dennis ES, et al. A sodium transporter (HKT7) is a candidate for Nax1,a gene for salt tolerance in durum wheat. Plant Physiol 2006;142:1718-27.

2. Kosova K, Prasil IT, Vitamas P. Protein contribution to plant salinity response and tolerance acquisition. Int J Mol Sci 2013;14:6757-89.

3. Ashraf MY, Rafique N, Ashraf M, Azhar N, Marchand M. Effect of supplemental potassium $\left(\mathrm{K}^{+}\right)$on growth, physiological and biochemical attributes of wheat grown under saline conditions. J Plant Nutr 2013;36:443-58.

4. FAO. Land and plant nutrition management service. 2008. Available via http://www.fao.org/ag b/agl/agll/spush/ (Accessed 24 July 2008).

5. Ashraf M. Some important physiological selection criteria for salt tolerance in plants. Flora 2006;199:361-76.

6. Igartua E, Grasia MP, Lasa JM. Field response of grain sorghum to salinity gradient. Field Crops Res 1995;42:15-25.

7. Ashraf M. Biotechnological approach of improving plant salt tolerance using antioxidants as markers. Biotech Adv 2009;27:84-93.

8. Jackson ML. Soil chemical analysis. Constable and Company, UK, 1962.

9. Wolf B. A comprehensive system of leaf analysis and its use for diagnosing crop nutrient status. Commun Soil Sci Plant Anal 1982;13:1035-59.

10. Steel RGD, Torrie JH, Dickey DA. Principles and procedures of statistics: a biometrical approach. McGraw Hill Co., New York, NY, pp 178-82, 1997.

11. Kausar A, Gull M. Effect of potassium sulphate on the growth and uptake of nutrients in wheat (Triticum aestivum L.) under salt stressed conditions. J Agric Sci 2014;6(8):101-12.

12. Redondo-Gomez S, Mateos-Naranjo E, Davy AJ, Fernández-Muñoz F, Castellanos E, Luque T, et al. Growth and photosynthetic responses to salinity of the salt-marsh shrub Atriplex portulacoides. Ann Bot 2007;100:555-63.

13. Ashraf MY, Wahid RA, Bhatti AS, Sarwar G, Aslam Z. Salt tolerance potential in differential in different Brassica species. Growth studies. In: Hamdy H, Lieth H, Todorovic M, Moschenko M (eds.). Halophytes uses in different climates-II. Backhuys Publishers, Leiden, The Netherlaands, pp 119-25, 1999.
14. Munns R, Tester M. Mechanisms of salinity tolerance. Ann Rev Plant Biol 2008;59:651-81.

15. Praxedes SC, Damatta FM, Lacerda CFD, José T, Prisco JT, Enéasgomes-Filho. Salt stress tolerance in cowpea is poorly related to the ability to cope with oxidative stress. Acta Bot Croat 2014;73(1): 51-62.

16. Shamme SK, Raghavaiah CV, Balemi T, Hamza I. Sorghum (Sorghum bicolor $\mathrm{L}$.) Growth, productivity, nitrogen removal, N- use efficiencies and economics in relation to genotypes and nitrogen nutrition in Kellem- Wollega zone of Ethiopia, East Africa. Adv Crop Sci Tech 2016;4(3):1-8.

17. Almodares A, Hadi MR, Dosti B. Effects of salt stress on germination percentage and seedling growth in sweet sorghum genotypes. J Biol Sci 2007;7(8):1492-5.

18. Abogadallah GM. Antioxidative defence under salt stress. Plant Signal Behav 2010;5:369-74.

19. Parida AK, Das AB. Salt tolerance and salinity effects on plants: a review. Ecotoxicol Environ Saf 2005;60:324-49.

20. Munns R. Comparative physiology of salt and water stress. Plant Cell Environ 2002;25:239-50.

21. Turan MA, Turkmen N, Taban N. Effect of $\mathrm{NaCl}$ on stomatal resistance and proline, chlorophyll, $\mathrm{Na}, \mathrm{Cl}$ and $\mathrm{K}$ concentrations of lentil plants. J Agron 2007;6(2):378-81.

22. Niu X, Bressen RA, Hasegawa MP, Pardo JM. Ion homeostasis in $\mathrm{NaCl}$ stress environments. Plant Physiol 1995;109:735-42.

23. Kafi M, Jafri MHS, Moayedi AA. The sensitivity of grain sorghum (Sorghum bicolor L.) developmental stages to salinity stress: an integrated approach. J Agric Sci Tech 2013;15:723-36.

24. Ashraf A, Khaid A, Ali K. Effects of seeding rate and density on growth and yield of rice in saline soil. Pak Biol Sci 1999;2:860-2.

25. Niu G, Xu W, Rodriguez D, Sun Y. Growth and physiological responses of maize and sorghum genotypes to salt stress. ISRN Agron 2012; Article ID 145072:1-12.

26. Shakeria E, Emama Y, Tabatabaeib SA, Sepaskhah AR. Evaluation of grain sorghum (Sorghum bicolor L.) lines/cultivars under salinity stress using tolerance indices. Int J Plant Prod 2017;11:101-16.

27. Sun Y, Niu G, Osuna P, Zhao L, Ganjegunte G, Peterson G, et al. Variability in salt tolerance of Sorghum bicolor L. Agric Sci 2014;2:9-21.

28. Tigabu E, Andargie M, Tesfaye K. Genotypic variation for salinity tolerance in Sorghum (Sorghum bicolor (L.) Moench) genotypes at early growth stages. J Stress Physiol Biochem 2013;9:253-62.

29. Rengasamy P. World salinization with emphasis on Australia. J Exp Bot 2006;57:1017-23.

30. Singh KN, Chatrath R. Salt tolerance. In: Reynolds MP, OrtizMonasterio JI, McNab A (eds.). Application of physiology in wheat breeding. CIMMYT. Mexico, 2001.

\section{How to cite this article:}

Kausar A, Gull M. Influence of salinity stress on the uptake of magnesium, phosphorus, and yield of salt susceptible and tolerant sorghum cultivars (Sorghum bicolor L.). J Appl Biol Biotech. 2019;7(03):53-58. DOI: 10.7324/JABB.2019.70310 